\title{
Note on the determination of net protein utilization by carcass analysis
}

\author{
By A. E. BENDER AND B. H. DOELL \\ Research Department, Bovril Ltd, I48 Old Street, London, E.C. I
}

(Received 24 August 1956)

In theory the measurement of net protein utilization (N.P.U.) refers to the particular protein under test. In practice there is a small amount of other nitrogen (including that from the vitamins) in the basal diet so that the actual measurement evaluates a mixture of test protein and this other nitrogen. In the diets that we have been using with rats (Miller \& Bender, 1955 ; Bender, 1956) the test diet was made up to contain $\mathrm{r} \cdot 69 \% \mathrm{~N}$; the non-protein diet contained $0.05-0 . \mathrm{r} \% \mathrm{~N}$.

In the subsequent discussion the following symbols are used: $I_{F}$, total dietary $\mathrm{N}$, comprising $I_{P}, \mathrm{~N}$ from test protein and $I_{K}$, other $\mathrm{N} ; F$, faecal $\mathrm{N} ; M$, metabolic $\mathrm{N}$; $U$, urinary $\mathrm{N} ; E$, endogenous urinary $\mathrm{N} ; B, B_{F}$ and $B_{K}$, initial carcass $\mathrm{N}$, carcass $\mathrm{N}$ of protein-fed animals and of non-protein group respectively.

Our original calculation (Bender \& Miller, I953) evaluated the total nitrogen of the diet, from the equation

$$
\text { N.P.U. }=\frac{B_{F}-B_{K}+I_{K}}{I_{F}} .
$$

The difference between this measurement and the N.P.U. of the test protein alone is insignificant except when very low values are being determined. A protein completely unavailable to the body would still have a small positive value, numerically equal to $I_{K} / I_{F}$ and entirely due to the other $\mathrm{N}$ of the diet.

In the general definition of net protein utilization

$$
\begin{aligned}
\text { N.P.U. }= & \text { B.v. } \times \text { digestibility } \\
= & \frac{I_{F}-(F-M)-(U-E)}{I_{F}-(F-M)} \times \frac{I_{F}-(F-M)}{I_{F}} \\
= & \frac{I_{F}-F+M-U+E}{I_{F}} .
\end{aligned}
$$

If only the test protein is considered, equation (2) becomes:

$$
\text { N.P.U. (test protein })=\frac{I_{1},-F+M-U+E}{I_{1}} \text {. }
$$

Then (according to the procedure of Bender \& Miller (I953)) $I_{P}-F-U$ (instead of $\left.I_{F}-F-U\right)$ is the gain in $\mathrm{N}$ by the protein-fed animal and $=B_{F}-B ;-M-E$ (instead of $I_{K}-M-E$ ) is the change in $\mathrm{N}$ incurred by the non-protein animal and $=B_{K}-B$. Hence

$$
\text { N.P.U. (test protein) }=\frac{B_{F^{\prime}}-B_{K}}{I_{I^{3}}}=\frac{B_{F^{\prime}}-B_{K}}{I_{F}-I_{K}} \text {. }
$$


The practical difference between equations ( $\mathrm{I}$ ) and (3) is shown in Table $\mathbf{I}$. With proteins of high N.P.U. the inclusion of the trace of $\mathrm{N}$ in the non-protein diet makes very little difference to the N.P.U. of the protein alone (equation (3)). With protein of very low N.P.U., however, as for example gelatin, with an expected N.P.U. of zero (Bender, Miller \& Tunnah, I953) the difference is appreciable.

Table I. Effect of corrected calculation on N.P.U. determinations of various proteins

Source of protein

\section{Dried defatted egg}

Bread fortified with lysine and threonine

Beef powder

Sesame meal

Meat meal

Wheat gluten

Heated sesame meal

Low-quality fish meal

Gelatin

$\begin{array}{cc}\begin{array}{c}\text { N.P.U. of total } \\ \text { nitrogen of diet } \\ \text { (equation (I)) }\end{array} & \begin{array}{c}\text { N.P.U. of protein } \\ \text { only } \\ \text { (equation (3)) }\end{array} \\ 93.0 & 92.5 \\ 77.6 & 76 \cdot 7 \\ 64 \cdot 0 & 62.5 \\ 57 \cdot 3 & 53 \cdot 7 \\ 40 \cdot 6 & 38 \cdot 5 \\ 31 \cdot 7 & 28.8 \\ 29.7 & 23.5 \\ 17.7 & 12.9 \\ 9.4 & 3.5\end{array}$

SUMMARY

The calculation of net protein utilization by the carcass-analysis method with rats is discussed and a minor modification suggested whereby either the total nitrogen of the diet or the test-protein fraction only may be evaluated.

\section{REFERENCES}

Bender, A. E. (1956). Brit. F. Nutr. 1o, 135 .

Bender, A. E. \& Miller, D. S. (1953). Biochem. F. 53, vii.

Bender, A. E., Miller, D. S. \& Tunnah, E. J. (1953). Chem. E' Ind. p. 799.

Miller, D. S. \& Bender, A. E. (1955). Brit. \%. Nutr. 9, 382. 